Др Добривоје Ольан

\title{
ACTIONES LIBERAE IN CAUSA
}

Случајеви кала исурачуиљивост ие искључује кривичну одговориост регулисани су ставом 3. чл. 12. КЗЈ који гласи:

„Кривично је одговоран учинилаи кривичног дсла који употребом алкохола, дроге или на други начин доведе себе у стане у хоме иије могао схватити зиачај свога дела или управљати својим поступцима, ако је, пре него што се довео у то стање дело било обухваһено његовнм умишљајсм или је у одиосу иа кривично дело код њега постојао иехат а закон за такво дело предвиһа одговорност и за нехат."

Да би се добро разумео иалред наведени текст потребно је знати и шта се подразумсва под умишљајсм и нехатом.

Умишъај је дефинисан чланом 13. КЗЈ који гласн:

„Кривично дело је учињено са умишљајем кала је учинилац био свестан свога дела и хтео његово извршење или кала је био свестан да услед његовог чиьеььа или нечиьења може наступити забрањсна последица, али је иристао иа њсно наступање."

IІехат је олрсһен чланом 14. КЗЈ:

„Кривично дело је учнњено из нехата када је учииилац био свестан да уследњсговог чињсња или нечиьсьь може наступити забрањена последица али је олако држао да he је моһи спречити или да она неһе иаступити; или кад иије био свестан могуһности иаступања забрањсне последине иако је према околиостима и према својим личним својствима био дужан и могао бити свестан те могуһности."

I. Кривично дело случајева actiones liberae in causa ако је извршсно са умишљајем састоји се из:

а. доношења одлуке да се изврии кривично дело,

b. довоһена себе у стаюе привремене душсвне поремеһености одиосно привремене иеурачунљивости,

- Аутор је спец неуропсихијатрије н судске пснхијатрије, шеф ахутног мушког одељен Неуропсихнјатрнјске болниче Ковин. 
с. извршена кривичие ральье.

Напред наведено се у прахси одвија на следеһи начин:

А. Доношење одлуке да се изврши кривично дело

1. Деликвентова мисао састоји се у томе да он да би за учињено кривично дело био оглашен за неурачунљнвог и на тај начин кривично неодговорноr треба да узме неко средство које he ra довести у стане привремене душевне поремсһености у хојем би своју иамеру извршио.

То зиачи да у време узимања средства којим се доводи у стање привремене душевне поремеһености учинилац може да схвати значај свога дела и да управља поступщима односно треба да је урачуиљив.

У судсконснхијатријској прахси се јављају посебни проблеми када горе наведено треба доказати. Докази се могу прибавити или на основу признања окривљеног нли на основу нсказа сведока којн су опет сазнањь о одлуин извршиоца могли стеһи пре његовог опијања односно стављања у стање привремене душевне поремећености, током опијања, у време извршења кривичног дела или иакон извршења кривнчног дела, при чему треба ценити всродостојност таквог сведочегь имају и у внду и трезвеност сведока, његове умне способности и карактерие особнне одиосно стварие побуде које га наводе да сведочн онако како баш сведочн.

2. Ако учниилащ дела приликом доношења одлуке и стављања себе у привремену душевну поремећеност није могао да схвати значај свога дела и да управља својим поступщима оцда ие постоји случај из става 3. чл. 12 К3Ј.

3. У случају да се учинилац не доведе у стање потпуне привремене неурачунљивости веһ у стање прнвремсне 6итно смањене урачунљивости постојн свакако кривична одговорност али се поставља питање да ли се том учнниоцу хазна може ублажити.

Став Врховних судова је да такав учннитаи не може уживати бенефиције код кажіьаваьь јер се и учинилаш у неурачунљивом стању у погледу кривичне одговорности и кажььаваьа изједначава по захону са урачунљивим извршиоцем па тако изједначаваьье тим вище мора да важи за учиниоца у стању битно смањене урачунљивости.

В. Довођење себе у стањеे привремсне душевне поремеһености односно приврсмсне нсурачунљивости

Постиже се иајчешһе узимањем алкохола али се могу користити и опојне дроге као и неки крвни и нервни отровн. Ова средства начелно посматрано треба с једне стране да нзазову прнвремену душевну поремеһеност а са друге стране да учиниоцу оставе могуһност да н у таквом стану своју намеру спроведе у дело, односно да може да управља својим поступком. Ако би узето средство изазвало такво стање да дотична особа не може да управља својим радњама онда и евентуално хривично дело не одговара пропису става 3. чл. 12. КЗЈ. То се догаһа или у случајевима тешког пијанства (препитости) нли у случајевнма абнорминх реакинја на алхохол.

Умншљајно стављање себе у привремену дуневну порсмеһеност садржи намеру да се у таквом стањь изврши крнвнчно дело бнло чињењем бнло нечињењем, односно пропуштањем потребног чињења. Код умишљајних кривичних дела извршених нечнњењем извршилаш је бно свестан да у ирнвременој душевној поремеһености неһе бити у стању да изврши потребно 


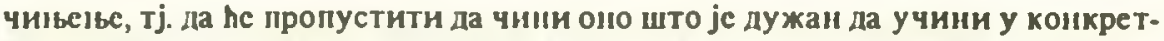
ном случају а то баш свесно и хоһе.

С. Извршсне иривнчис радље

Зависн од могуһности алкохолисане особе (односно на други начин стављене у стањье привремене душсвие поремсһеностн) да у критичном часу сврсксходно улотрсби своје психофизичке способностн (чула и удове) и да сврсисходно употре6н оруһе или оружје.

II. Кривично дело случајева actiones liberac in causa ако је извршено из нехата састоји се из:

а. довоһења себе у стаље привремене неурачунљивости

b. извршена кривнчне радыье

A. Нехатно стављање себе у прнвремену душевну лоремеһеност јавља се у два внда:

Први је случај кала учннилац олако држи да довоһењем себе у стање привремене душевне поремеһености неће проузоковати забрањену последину.

Други је случај хад учинилаи није био свестан да може доһи до забрањене последище али је бно дужан и могао да буде тога свестан.

Овахва кривнчна дела из нехата најчешһе су последияе немарног, не6рижљнвог и несавесног вршења професионалне дужности.

Другим речима, сматра се да је поједннаи дужан, односно обавезан према својој професији да не употреби средство које би ьегово здравствено стање лореметило и на тај начии изазвало неспособност правилног вршења занимања, што за последишу има кривично дело. У пракси се оваквн случајеви јављају код управљача моторног возила, других службеника у јавном саобраһају, радника ITТ службе или здравствених радника.

У циљу што потпунијег сагледавања ове материје треба поменути и оне случајеве хада нема кривичне одговорностн у смислу става 3. чл. 12 КЗЈ.

1. Код умишљајног кривичног дела случајева actiones liberae in causa треба да постоји одреһена намера која је саставни део умишлаја. Тако на пример „нема крнвичне одговорности ако лине хоје се стави у стање привремене душевне поремеһености учнни кривично дело које није нити је могло бити обухваһено његовим предвијањсм".

2. Коднехатиог кривичног де ла случајева actiones liberae in causa не може 6ити кривичне одговорности ако то дело није у захону инкриминисано. Такоһе „нема крнвнчне одговориости ахо је лище могло битн свесно да може нзвршити ма које крнвично дело јер је потребно да се виност односи на оцређено кривнчно дело" (виност је психичхн однос учиниоца према делу хоји се изражкава у свести и вољи учиниоца).

На крају лотребно је реһи да када се учннилац хахњава зато игто је у трезном стању одтучио да изврши кривично дело које је потом извршио de fасто у стању привремене неурачунљивости онда се то чнни у циљу заштите правног поретка а не у смислу суштнне одредбе о урачунљивости. 